\title{
Kesantunan Respon Tuturan Direktif dalam Film Alangkah Lucunya Negeri Ini
}

\author{
Putri Caesar Ramadhani ${ }^{1}$, Imam Suyitno ${ }^{1}$, Nurchasanah ${ }^{1}$ \\ ${ }^{1}$ Pendidikan Bahasa Indonesia-Universitas Negeri Malang
}

\begin{tabular}{l}
\hline \hline INFO ARTIKEL \\
\hline Riwayat Artikel: \\
Diterima: 12-01-2019 \\
Disetujui: 11-03-2019 \\
\hline
\end{tabular}

\section{Kata kunci:}

politeness;

response;

directive speech;

movie;

kesantunan;

respon;

tuturan direktif;

film

Alamat Korespondensi:

Putri Caesar Ramadhani

Pendidikan Bahasa Indonesia

Universitas Negeri Malang

Jalan Semarang 5 Malang

E-mail: putricaesar.pcr@gmail.com

\section{ABSTRAK}

Abstract: This qualitative research aims described the politeness of response to the directive speech in the movie Alangkah Lucunya Negeri Ini. This study uses a qualitative approach to the type of social ethnographic research, especially sociopragmatic. The results showed that the politeness response in the movie Alangkah Lucunya Negeri Ini emphasized from the (1) forms, (2) functions, and (3) strategies of speech. Each of that showed the politeness response directive speech.

\begin{abstract}
Abstrak: Penelitian kualitatif ini bertujuan untuk mendeskripsikan kesantunan respon terhadap tuturan direktif dalam film Alangkah Lucunya Negeri Ini. Penelitian ini menggunakan pendekatan kualitatif dengan jenis penelitian etnografi sosial, khusunya sosiopragmatik. Hasil penelitian menunjukkan bahwa Kesantunan Respon dalam film Alangkah Lucunya Negeri Ini dapat dilihat dari segi (1) wujud, (2) fungsi, dan (3) strategi tuturan. Masing-masing aspek menunjukkan kesantunan dalam merespon tuturan direktif.
\end{abstract}

Bahasa merupakan alat komunikasi yang sangat penting bagi manusia. Dalam komunikasi, pesan yang ingin disampaikan oleh penutur bisa diterima oleh mitra tutur dengan menggunakan bahasa. Komunikasi bahasa merupakan proses sosial karena setiap tuturan yang dipilih sesuai norma-norma, perasaan, dan berbagai harapan yang disadari secara sosial. Oleh sebab itu, fenomena kebahasaan bukan hanya diamati sebagai sistem atau struktur bahasa, melainkan sebagai fenomena sosial bahkan fenomena kultur. Kedua fenomena kebahasaan tersebut merupakan kesatuan yang utuh dan terpadu (Ibrahim, 2012).

Kesantunan maupun kesopanan dalam bertutur perlu diperhatikan demi menjalin keharmonisan hubungan antara penutur dengan mitra tutur. Chojimah (2015) menyampaikan bahwa konsep kesantunan hadir dalam semua bahasa, tetapi setiap bahasa memiliki caranya sendiri dalam mewujudkan kesantunan. Bahasa sangat lekat dengan interaksi sosial dan tidak semua penutur memperhatikan kesantunan berbahasa ketika berinterakksi dengan satu sama lain. Penutur dan mitra tutur cenderung berbahasa sesuai dengan kepentingan dan keperluan komunikasi, terlepas dari tuturan tersebut dikategorikan santun atau tidak. Padahal, secara tidak langsung kesantunan dalam berbahasa mencerminkan sikap atau perilaku serta identitas sosial seseorang. Kartomiharjo (2013) menyebutkan bahwa fungsi bahasa adalah untuk menunjukkan identitas sosial budaya pemakainya, tidak hanya sekadar untuk berkomunikasi. Dengan demikian, sudah sepatutnya pengguna bahasa memperhatikan kesantunan dalam berbahasa dalam berkomunikasi.

Penggunaan tindak tutur direktif dalam suatu komunikasi bahasa tidak lepas dari maksud dan tujuan tuturan tersebut. Ibrahim (2013) mendefinisikan tindak tutur direktif sebagai tindak tutur yang mengekspresikan sikap penutur terhadap tindakan yang akan dilakukan oleh mitra tutur. Tindak direktif merupakan tindak tutur yang berfungsi mendorong penanggap tutur melakukan sesuatu, misalnya mengusulkan, memohon, mendesak, menentang, memerintah, dan sejenisnya (Suyono, 2009). Tindak direktif dilakukan seseorang agar seseorang yang dimaksudkan melakukan hal yang dia inginkan sehingga muncul respon yang diharapkan dari tindak direktif ini. Leech (2013) mengungkapkan bahwa tindak tutur direktif merupakan bentuk tindak tutur yang dimaksudkan penutur untuk membuat pengaruh agar mitra tutur melakukan suatu tindakan. Baik atau tidaknya bentuk respon tersebut bergantung pada kesantunan penutur dalam menyampaikan tuturannya. Kesantunan tuturan dalam memberikan respon itulah yang akan diteliti dan dikaji dalam penelitian ini. 
Kesantunan tuturan dalam merespon tuturan direktif tidak hanya dipandang sebagai sebuah kesantunan dalam menyikapi tuturan mitra tuturnya dengan memberikan respon tertentu. Dibalik itu, ada hal-hal yang perlu diperhatikan, yakni wujud kesantunan, fungsi kesantunan, dan strategi kesantunan dalam merespon. Pada kegiatan berkomunikasi, penutur cenderung mengabaikan hal-hal tersebut. Tuturan maupun tindakan yang ditunjukkan sebagai bentuk atau wujud respon tidak menunjukkan kesantunan penutur. Misalnya, suatu respon diwujudkan dalam bentuk verbal dengan menggunakan kalimat atau pilihan bahasa yang tidak baik atau intonasi meninggi yang menunjukkan ketidaksantunan respon tersebut. Penutur juga cenderung mengabaikan fungsi kesantunan bahasa sebagai cara untuk menjaga keharmonisan hubungan antara penutur dan mitra tutur. Terlebih, penutur merasa strategi dalam menyampaikan respon bukanlah suatu hal yang patut dipermasalahkan, melainkan pesan yang mudah diterima, itulah yang penting. Rahmat (2009) menjelaskan bahwa respon adalah setiap jenis kegiatan yang ditimbulkan oleh suatu perangsang. Soenarjo (2013) mengungkapkan bahwa istilah respon dalam komunikasi adalah kegiatan yang diharapkan mempunyai hasil yang diakhiri dengan efek. Dalam berkomunikasi, setiap stimulus atau rangsang ucapan yang disampaikan oleh penutur merupakan bentuk untuk memperoleh efek, baik berupa respon verbal maupun nonverbal. Kaitannya dalam tuturan direktif, stimulus tersebut digunakan dengan maksud agar lawan bicara memberikan respon sesuai dengan yang dikehendaki oleh penutur.

Dalam penelitian ini peneliti berusaha mengkaji kesantunan respon atas tuturan direktif yang terdapat dalam interaksi sosial, baik formal maupun informal. Goffman (dalam Rofi'uddin 2015) menjelaskan bahwa interaksi sosial adalah perilaku komunikatif, baik yang bersifat verbal maupun nonverbal, antarindividu atau antarkelompok individu yang terjadi secara fisik. Kesantunan respon direktif dalam komunikasi interaksi sosial bisa berupa respon verbal maupun tindakan berdasarkan stimulus yang diberikan. Interaksi sosial tersebut bisa diperoleh dari tuturan dalam film. Film merupakan potret kehidupan sosial dengan adegan-adegan dan topik tertentu yang berfungsi sebagai media penyampaian pesan yang efektif. Trianton (2013) menjelaskan bahwa media disebut juga alat-alat audio visual, seperti televisi dan film, artinya alat yang dapat dilihat dan didengaar yang dipakai dalam proses pembelajaran dengan maksud untuk membuat cara berkomunikasi lebih efisien. Film sebagai salah satu media penyiaran mampu masuk dan diterima dengan mudah oleh berbagai lapisan masyarakat sehingga bisa digunakan sebagai sarana menyampaikan informasi pendidikan yang terkait dengan pembelajaran bahasa.

Film adalah bagian dari produk budaya yang didalamnya memuat nilai-nilai budaya sehingga film juga menjadi media efektif untuk menanamkan nilai budaya atau nilai pendidikan. Film merekam realitas fisik, tetapi melihatnya secara berbeda dari pengalaman manusia biasa. Dalam satu penggunaan, film adalah medium komunikasi massa, yaitu alat penyampaian berbagai jenis pesan dalam peradaban modern saat ini. Sebagai alat penyampaian berbagai jenis pesan, film diharapkan memberikan informasi atau tayangan yang sesuai dengan fakta yang ada di lapangan. Film menggunakan bahasa sebagai alat untuk memberikan informasi kepada pemirsanya. Bahasa diibaratkan sebagai "jembatan” yang menghubungkan penyampaian informasi di layar kaca dengan pemirsa atau masyarakat yang menyaksikan film tersebut. Jadi, media film tidak bisa dipisahkan dengan bahasa (Sumarno, 2006). Goddard (2002) menjelaskan bahwa ada hubungan serius antara bahasa, masyarakat dan budaya karena sejak lama budaya telah menunjukkan bahwa bahasa yang digunakan dalam bermasyrakat dapat menunjukkan kelas-kelas tertentu.

Film sebagai media pembelajaran juga diharapkan mampu mengembangkan kognitf bahasa siswa. Beberapa jalur penelitian menunjukkan efek pembelajaran yang berbeda dari berbagai bentuk media. Yuka (2000) menyampaikan pentingnya informasi tentang kesopanan positif dan strategi dalam buku teks untuk mencapai salah satu tujuan utama subjek; untuk menumbuhkan sikap positif menuju komunikasi. Akan tetapi, tidak hanya buku teks, media film pun bisa dimanfaatkan sebagai media pembelajaran untuk menyampaikan informasi tersebut. Dalam penelitiannya, Yasri dan Mulyani (2016) menjelaskan bahwa siswa cenderung lebih banyak memahami hal-hal yang terinterpretasikan dalam film daripada dalam buku teks. Disebutkan pula bahwa film mampu memberikan pengalaman belajar yang tidak didapatkan siswa di dalam kelas karena keterbatasan ruang dan waktu yang mereka miliki. Hal ini juga dapat mengasah kemampuan analitis siswa terhadap film yang ditampilkan berdasarkan teori dan konsep yang telah mereka pelajari sebelumnya. Dalam film terdapat dialog-dialog yang memungkinkan adanya tuturan direktif sebagai bentuk komunikasi. Film yang akan digunakan sebagai objek penelitian adalah film Alangkah Lucunya Negeri Ini. Pemilihan film ini didasarkan pada tema film yang kompleks, yakni mengandung tema ekonomi, pendidikan, politik, dan hukum didalamnya sehingga bisa dijadikan pertimbangan sebagai sumber belajar siswa kaitannya dengan kontribusi dalam bidang pendidikan.

Penelitian ini bukanlah penelitian yang pertama kali dilakukan tentang kesantunan respon maupun analisis bahasa dalam film. Sebelumnya, terdapat beberapa penelitian yang juga mengkaji topik tersebut. Pertama, penelitian yang dilakukan Masfufah pada tahun 2010 yang berjudul Kesantunan Bentuk Tuturan Direktif di Lingkungan SMA Negeri 1 Surakarta. Kedua, penelitian yang dilakukan Febriana yang berjudul pada tahun 2011 dengan judul Tuturan Responsif Siswa terhadap Tuturan Direktif Guru dalam Wacana Interaksi Kelas di SMA Negeri 1 Batu. Ketiga, penelitian yang dilakukan oleh Kristanti pada tahun 2014 yang berjudul Tindak Tutur Direktif dalam Dialog Film “Ketika Cinta Bertasbih" Karya Chaerul Umam. Adapun persamaan dan perbedaan penelitian ini dengan tiga penelitian terdahulu sebagai berikut. Pertama, persamaan dengan penelitian yang dilakukan Masfufah yakni keduanya mengkaji tentang kesantunan bahasa dan kaitannya dengan tuturan direktif, perbedaannya penelitian ini tuturan yang dikaji adalah respon dari tuturan direktif, sedangkan milik Masfufah terhadap bentuk tuturan direktif. Kedua, persamaan dengan penelitian yang dilakukan oleh Febriana yakni keduanya mengkaji tentang tuturan respon, perbedaannya terletak pada objek yang dikaji, milik Febriana mengkaji wacana kelas, sedangkan dalam penelitian ini 
wacana dalam film. Ketiga, persamaan dengan penelitian yang dilakukan oleh Kristanti yakni keduanya mengkaji tentang tuturan direktif pada film, perbedaannya pada penelitian ini fokus yang dikaji adalah kesantunan respon tuturan direktif, sedangkan penelitian Kristanti fokus pada tuturan direktif saja.

\section{METODE}

Pendekatan yang digunakan dalam penelitian ini adalah kualitatif dengan metode analisis percakapan. Pendekatan penelitian dengan mengkaji atau menganalisis isi percakapan dalam film, baik dari tampilan luar maupun makna yang tersembunyi dari suatu percakapan. Pemilihan pendekatan kualitatif dengan metode analisis percakapan dalam penelitian ini didasari oleh berbagai pertimbangan sebagai berikut. Pertama, data dalam penelitian ini bersifat alamiah, yakni kesantunan respon tuturan direktif dalam film. Alamiah dalam arti tuturan yang muncul murni dari film dan tidak ada perlakuan apapun dari peneliti dalam kemunculan data. Kedua, data dalam penelitian ini bersifat verbal sehingga peneliti harus mentranskrip tuturan untuk dapat dijadikan sebagai data penelitian. Ketiga, peneliti melakukan analisis data dalam penelitian ini secara induktif sehingga mendapatkan sebuah kesimpulan. Penelitian ini termasuk dalam jenis penelitian etnografi sosial, khususnya kajian sosiopragmatik. Selain berhubungan dengan bahasa dalam lingkup sosial, penelitian ini juga berkaitan dengan pragmatik bahasa tersebut.

Penelitian ini mengkaji kesantunan tuturan-tuturan pemain yang ada dalam film beserta konteksnya. Dalam penelitian ini kesantunan respon tindak direktif (dimaknai sebagai tuturan secara umum, belum ditentukan jenis tuturannya) dipandang sebagai tindak tutur dan produk tindak tutur. Sebagai tindak tutur dan produk tindak tutur, respon tuturan direktif tersebut dideskripsikan berdasarkan wujud, fungsi, dan strategi. Kajian difokuskan kepada kesantunan respon tuturan direktif yang dituturkan oleh semua pemain dalam film. Sumber data dalam penelitian ini adalah tuturan respon berdasarkan tuturan direktif dalam film Alangkah Lucunya Negeri Ini. Sumber data diperoleh dari dialog yang terdapat dalam film tersebut. Data dalam penelitian ini adalah transkip tuturan respon berdasarkan tindak direktif yang menunjukkan (a) wujud kesantunan respon tuturan direktif dalam film, (b) fungsi kesantunan respon tuturan direktif dalam film, dan (c) strategi kesantunan respon tuturan direktif dalam film.

Dalam penelitian ini, peneliti berperan sebagai instrumen kunci sekaligus evaluator. Dalam penelitian kualitatif, peneliti memang bisa memiliki berbagai peran, antara lain sebagai perancang penelitian, pengumpul data, pengolah data, dan pelapor hasil temuan penelitian. Terkait peran peneliti sebagai instrumen, peneliti harus dipandu beberapa pedoman agar keobjektifan dan keabsahan dalam menghasilkan penelitian tetap terjamin. Beberapa pedoman penelitian tersebut berupa pedoman pengumpulan data dan pedoman analisis data. Panduan dalam pengumpulan data antara lain, tabel indikator, pedoman pentranskripan data, dan pedoman kodifikasi data. Tabel indikator sebagai pedoman yang penting dalam penelitian ini berupa pedoman yang berisi tabel indikator yang menunjukkan bentuk tuturan direktif. Indikator-indikator tersebut memudahkan peneliti untuk mengumpulkan data yang berupa tuturan direktif -beserta responnya. Selanjutnya, data berupa dialog tersebut direkam dan ditranskrip berdasarkan pedoman yang telah ditentukan. Data yang sudah ditranskrip kemudian dikodifikasi menggunakan pedoman kodifikasi data. Panduan dalam penganalisisan data berupa pedoman analisis, interpretasi, dan inferensi data. Pedoman ini hampir sama dengan tabel indikator dalam mengumpulkan data, tetapi indikator lebih kompleks disesuaikan dengan kebutuhan untuk memenuhi rumusan masalah yang ditentukan.

Analisis data dalam penelitian ini dilakukan dengan menggunakan pendekatan pragmatik. Bogdan dan Biklen menjelaskan bahwa pengolahan data dalam penelitian kualitatif pada dasarnya merupakan suatu upaya untuk bekerja dengan data, mengorganisasikan data, diklasifikasikan menjadi data-data yang siap dan dapat dianalisis, menyimpulkannya menjadi pola-pola yang dapat dipelajari dan disampaikan kepada orang lain. Secara sederhana, proses analisis data merupakan kegiatan untuk mengatur data, mengurutkan, mengklasifikasikan, memberi kode, dan melakukan pemaknaan berdasarkan teori agar bisa diperoleh penyimpulan untuk menjawab masalah atau fokus penelitian yang dikaji. Proses analisis data dipilih sesederhana mungkin untuk memudahkan pengolahan data yang masih berantakan agar bisa dipahami dengan mudah dan dimaknai dengan baik.

Penelitian ini memodifikasi tahapan berdasarkan pemikiran Miles dan Huberman, yakni transkripsi, reduksi, kodifikasi, klasifikasi, analisis, dan penyimpulan. Proses transkripsi merupakan proses dari mengubah dari bentuk rekaman suara menjadi bentuk naskah untuk mempermudah penganalisisan. Selanjutnya, reduksi dilakukan dengan mengeliminasi data-data yang tidak memenuhi syarat sesuai dengan aspek masalah. Kodifikasi dilakukan dengan memberi kode pada tuturan yang sesuai dengan kebutuhan masalah guna mempermudah analisis data secara keseluruhan. Selanjutnya, klasifikasi dilakukan dengan cara memetakan data berdasarkan rumusan masalah, yakni data tuturan respon direktif berdasarkan fungsi, wujud, dan strategi. Selanjutnya, peneliti melakukan analisis data sesuai dengan aspek yang akan diteliti. Terakhir, penyimpulan dilakukan setelah semua data selesai dianalisis.

\section{HASIL DAN PEMBAHASAN}

Kesantunan respon tuturan direktif merupakan tata cara bertutur seseorang dalam merespon tuturan-tuturan direktif yang dituturkan oleh orang lain. Santun atau tidaknya respon tersebut ditunjukkan dari wujud, fungsi, dan strategi yang digunakan untuk merespon tuturan direktif dalam film Alangkah Lucunya Negeri Ini. Masing-masing aspek wujud, fungsi, dan 
strategi respon tersebut menunjukkan derajat kesantunan dari penutur dalam merespon tuturan direktif yang diterima dari mitra tuturnya. Derajat kesantunan yang ditemukan menunjukkan bahwa tidak sepenuhnya respon yang diberikan memiliki kesantunan yang baik.

Berdasarkan hasil temuan, penelitian ini menunjukkan bahwa pertama, berdasarkan wujudnya, kesantunan respon memiliki dua wujud yakni berupa (1) verbal, terdiri atas kalimat deklaratif, kalimat interogatif, imperatif dan (2) nonverbal, terdiri atas isyarat dan tindakan. Kedua, berdasarkan fungsi kesantunannya, respon tuturan direktif memiliki dua fungsi utama yakni fungsi menolak dan melaksanakan. Masing-masing fungsi tersebut dibagi lagi menjadi fungsi khusus, yakni (1) menghargai orang lain, (2) merendahkan orang lain, (3) menunjukkan status, (4) menunjukkan kondisi, (5) menunjukkan emosi, (6) menolak persetujuan, (7) menantang, (8) meminta penjelasan, (9) melarang, (10) mengajak, dan (11) mencapai tujuan mitra tutur. Ketiga, berdasarkan strateginya kesantunan respon ditunjukkan dengan dua cara yakni secara langsung dan tidak langsung, respon menolak secara tidak langsung dibagi tiga temuan, yakni (1) menggunakan alasan, (2) menerima tetapi tidak pasti, dan (3) menggunakan ancaman, sementara itu strategi kesantunan respon melaksanakan tidak langsung terdapat tiga temuan, yakni (1) dengan tindakan dengan isyarat, (2) menggunakan pertanyaan, dan (3) dengan permintaan.

\section{Wujud Kesantunan Respon Tuturan Direktif dalam Film Alangkah Lucunya Negeri Ini}

Pada bagian wujud kesantunan respon tuturan direktif, ditemukan dua wujud respon, yakni respon menolak dan melaksanakan. Dalam setiap stimulus yang diberikan oleh penutur terhadap mitra tutur, tentu diharapkan respon dari mitra tutur. Soenarjo (2013) mengungkapkan bahwa istilah respon dalam komunikasi adalah kegiatan yang diharapkan mempunyai hasil yang diakhiri dengan efek. Efek atau respon yang muncul bergantung dari stimulus yang diberikan atau tuturan yang disampaikan. Respon yang muncul dari mitra tutur bisa berupa respon positif maupun respon negatif. Respon menolak atau penolakan dari mitra tutur atas tuturan direktif yang dinyatakan penutur merupakan salah satu wujud dari respon negatif.

Berdasarkan hasil penelitian, wujud kesantunan menolak dan melaksanakan dalam tuturan direktif dibagi lagi menjadi dua, yakni wujud respon menolak verbal dan nonverbal. Pada wujud kesantunan menolak dan melaksanakan secara verbal dikerucutkan berdasarkan jenis tuturan pada tuturan tersebut, yakni deklaratif, interogati, dan imperatif, sedangkan wujud nonverbal dibagi menjadi isyarat dan tindakan. Berikut ini pembahasan mengenai kesantunan respon berdasarkan wujud tuturannya.

\section{Wujud Kesantunan Menolak secara Verbal}

Wujud verbal merupakan wujud kesantunan respon tuturan direktif berupa tuturan dari mitra tutur berdasarkan stimulus yang diberikan penutur. Wujud verbal itu bisa berupa kalimat yang dituturkan oleh penutur. Pada respon verbal yang dinyatakan mitra tutur terhadap tuturan direktif penutur ditemukan tiga wujud tuturan verbal berdasarkan istilah strukturalnya, yakni kalimat verbal deklaratif, interogatif, dan imperatif. Rahardi (2015) membagi wujud tuturan menjadi dua kategori utama, yakni direktif bermodus imperatif dan nonimperatif (deklaratif dan interogatif). Wujud tuturan imperatif yakni mengandung maksud memerintah atau meminta agar mitra tutur melakukan suatu sebagaimana diinginkan oleh penutur. Wujud tuturan deklaratif yakni mengandung maksud memberitakan sesuatu kepada mitra tutur. Sesuatu yang diberitakan tersebut lazimnya berupa suatu peristiwa atau kejadian. Wujud tuturan interogatif yakni mengandung maksud menanyakan sesuatu kepada mitra tutur. Berikut ini kutipan data yang menunjukkan wujud kesantunan respon.

Pipit: Tunggu sebentar. Mau nitip. [Pipit mau masuk kembali ke rumah]

Muluk: Jangan sekarang Pit. Abang ada perlu. [WT/17.1/MOH/V.Dek]

Komet: Bos bilang, urus anak buah masingmasing. Kalo lu mau ngemplang kepala, kemplang aja kepala anak buah lu.

Glen: Terserah gue. Sekarang kepala lu aja yang gue kemplang, ya?

Komet: Ayo kalo berani. [WT/15.2/NAS/V.Int]

Muluk: Pagi-pagi udah mulai. Sul, lo kan sarjana pendidikan, harusnya elo ngajar.

Samsul: Nah lo? mestinya jadi direktur. Lu kan sarjana manajemen.

Teman-teman: Hahahahahahaah

Muluk: (diam) [ WT/07.1/NAS/V.Imp]

Dari ketiga data di atas, tampak bahwa respon berdasarkan tuturan direktif dapat berwujud kalimat deklaratif, interogatif, maupun imperatif. Akan tetapi, ketiganya merupakan wujud penolakan dari penutur atas tuturan direktif yang diberikan oleh mitra tutur. Masing-masing dari wujud respon di atas, memiliki derajat kesantunan yang berbeda. Wujud respon pada data [WT/17.1/MOH/V.Dek] menunjukkan bahwa respon yang disampaikan penutur memiliki kesantunan yang baik. Penutur berupaya menolak dengan menyampaikan alasan mengapa penutur tidak dapat memenuhi permohonan mitra tuturnya. Sementara itu, data [WT/15.2/NAS/V.Int] dan [WT/07.1/NAS/V.Imp] tampak adanya penolakan yang tidak menunjukkan kesantunan dari mitra tutur. Kedua penolakan tersebut dianggap tidak santun, karena pada data [WT/15.2/NAS/V.Int], penutur justru menyampaikan penolakan disertai upaya untuk menantang mitra tuturnya. Hal itu jelas tidak santun karena merugikan 
mitra tuturnya. Pada data [WT/07.1/NAS/V.Imp], respon tersebut dianggap tidak santun karena penutur merendahkan mitra tutur dengan menyinggung status pekerjaannya.

\section{Wujud Kesantunan Menolak secara Nonverbal}

Wujud nonverbal merupakan kesantunan respon tuturan direktif dari mitra tutur yang bukan berupa verbal (lisan) atau tuturan. Dalam kehidupan sehari-hari, keterkaitan kesantunan dengan perilaku yang pantas mengisyaratkan bahwa kesantunan tidak hanya berkaitan dengan bahasa, tetapi juga dengan perilaku non-verbal (Nurjamily, 2015). Pada penelitian ini ditemukan dua wujud respon nonverbal yang ditunjukkan mitra tutur terhadap tuturan direktif penutur, yakni berupa isyarat dan tindakan. Wujud nonverbal kesantunan menolak berupa isyarat merupakan wujud kesantunan yang dinyatakan mitra tutur melalui gerakan yang mengandung makna tertentu, misalkan gerakan tangan, kepala, mata, dan sebagainya. Makna dari iyarat yang berupa gerakan tangan, kepala, mata, dan sebagainya itu disinyalir bentuk dari sebuah penolakan atau ketidaksetujuan berdasarkan tuturan direktif yang distimulasikan oleh penutur lain. Penggunaan isyarat sebagai wujud nonverbal penolakan dianggap bisa menggambarkan kesantunan dari respon tersebut. Sama halnya dengan isyarat, wujud respon secara nonverbal berupa tindakan merupakan wujud penolakan tanpa mengucapkan tuturan, tetapi dari tindakan yang dilakukan oleh penutur tersebut mampu menggambarkan bahwa penutur tersebut menolak tuturan direktif yang disampaikan mitra tuturnya. Berikut contoh respon menolak secara nonverbal.

Haji Sarbini: Alhamdulillah gue nggak saleh. Si Idham abangnye si Rahma yang tamatan aliyah sekarang udah punya kios di Cipulir dan udah berangkat haji. Adeknya Alamsyah, yang tamatan tsanawiyah sekarang udah punya usaha sablon dan konveksi kecilkecilan, insyaallah tahun ini berangkat haji.

Rahma: Ah, Babe. Itu melulu yang diulang-ulang.

Haji Sarbini: (melirik sinis)

Bang Jarot: (memandangi Glen)

Glen! Yang mau tetap nyopet,

silahkan. Ini negara bebas. Tapi sekali lagi, yang ganggu temannya yang ngasong, awas! (a)

Glen: (melengos dan pergi keluar)

Data di atas menunjukkan bahwa respon penolakan bisa berupa isyarat dan tindakan. Isyarat yang dimaksudkan adalah berupa lirikan sinis yang diartikan sebagai ketidakinginan perespon untuk memenuhi larangan mitra tuturnya. Sementara itu pada respon berupa tindakan melengos dan pergi dianggap respon penolakan karena perespon tidak ingin mendengarkan larangan-larangan dari mitra tutur yang tidak sepemahaman dengannya. Keduanya memiliki kesantunan yang kurang baik, karena sebuah respon apabila ditunjukkan tanpa disertai tuturan apapun dianggap tidak sopan. Dalam berkomunikasi, penutur harus berupaya untuk memanjangkan kalimatnya atau tidak secara langsung menunjukkan maksudnya, juga dijelaskan bahwa semakin panjang tuturan seseorang maka semakin besar pula keinginan seseorang untuk bersikap santun.

\section{Wujud Kesantunan Melaksanakan secara Verbal}

Wujud kesantunan respon melaksanakan merupakan wujud kesantunan respon yang berupa persetujuan atas tuturan direktif yang dituturkan atau distimulasikan penutur kepada mitra tutur pada film Alangkah Lucunya Negeri Ini. Berdasarkan hasil penelitian, pada bagian ini terdapat dua wujud kesantunan respon melaksanakan, yakni wujud verbal dan nonverbal dalam melaksanakan tuturan direktif. Sama halnya dengan wujud verbal kesantunan menolak, wujud verbal kesantunan melaksanakan juga merupakan wujud kesantunan yang berupa pernyataan baik kalimat maupun kata atau ungkapan dari mitra tutur sebagai bentuk respon dari tutuan direktif yang disampaikan penutur. Wujud verbal kesantunan melaksanakan dibagi menjadi tiga, yakni berupa kalimat deklaratif, interogatif, dan imperatif. Dari beberapa data yang dianalisis pada bagian ini, sebagian besar di antaranya menunjukkan kesantunan yang baik. Berikut data yang mendukung temuan tersebut.

Bang Jarot: Baik, saya akan hajar mereka supaya mau.

Muluk : Oh, jangan.

Bang Jarot: Jadi bagaimana?

Respon di atas berupa kalimat interogatif atau pertanyaan yang menunjukkan bahwa di samping perespon berusaha untuk memenuhi tuturan direktif yang disampaikan mitra tuturnya, perespon juga bertanya hal yang harus dia lakukan akibat larangan dari mitra tuturnya itu. Dari segi kesantunan, respon pelaksanaan tersebut dianggap santun karena dalam berkomunikasi sesuai konteks percakapan di atas, penutur berusaha untuk memaksimalkan keuntungan mitra tutur dengan berusaha memenuhi keinginannya.

\section{Wujud Kesantunan Melaksanakan secara Nonverbal}

Wujud nonverbal dalam rangka melaksanakan tuturan direktif dalam penelitian ini berupa isyarat dan tindakan. Isyarat yang dimaksud adalah berupa gerakan anggota tubuh, dapat berupa mata, tangan, dan sebagainya yang memiliki makna bahwa perespon bersedia melaksanakan tuturan direktif yang disampaikan oleh mitra tutrunya. Poerdawarminta (2009) respon 
diartikan sebagai tanggapan, reaksi, dan jawaban. Tanggapan, reaksi, dan jawaban tersebut tidak sepenuhnya berupa tuturan. Isyarat dan tindakan juga bias dianggap sebagai respon dalam melaksanakan tuturan direktif. Berikut data yang menunjukkan respon melaksanakan secara nonverbal.

Muluk: Ini bagian proses pendidikan,

penyadaran. Mungkin harus lebih bersabar.(f)

Bang Jarot : (mengangguk-angguk) $(\mathrm{g})$

Pada contoh di atas, menggangguk merupakan wujud respon berupa nonverbal yakni isyarat yang menunjukkan bahwa perespon menyetujui atau bersedia memerima nasihat yang diberikan oleh mitra tuturnya. Sebetulnya anggukan tersebut dianggap tidak sepenuhnya memiliki derajat kesantunan yang baik, karena perespon tidak mengucapkan tuturan sepatah kata pun untuk menyertai anggukan tersebut. Akan tetapi, upaya untuk mau memenuhi atau menyetujui nasihat yang disampaikan oleh mitra tuturnya dianggap sebagai bentuk respon yang santun karena perespon memaksimalkan kerendahan hati dengan tujuan menghormati nasihat yang disampaikan orang lain.

\section{Fungsi Kesantunan Respon Tuturan Direktif dalam Film Alangkah Lucunya Negeri Ini}

Fungsi kesantunan respon tuturan direktif dalam film Alangkah Lucunya Negeri Ini terbagi atas dua kategori besar, yakni fungsi kesantunan respon menolak dan fungsi kesantunan respon melaksanakan. Fungsi kesantunan respon menolak tersebut dibagi lagi sesuai dengan wujud responnya, yakni fungsi kesantunan respon berupa verbal dan nonverbal. Dari jenis kesantunan verbal, terdapat fungsi respon yang dinyatakan dalam kalimat deklaratif, interogatif, dan imperatif, sedangkan fungsi kesantunan nonverbal dinyatakan dalam bentuk isyarat dan tindakan. Masing-masing wujud tersebut memiliki fungsi yang berbeda-beda seperti yang telah dijabarkan pada penjelasan sebelumnya.

Secara umum, dikaji berdasarkan fungsi bahasa, masing-masing fungsi kesantunan respon dalam film Alangkah Lucunya Negeri Ini dibagi memiliki tiga fungsi, yakni fungsi ekspresif, informatif, dan argumentatif. Walaupun fungsi berupa nonverbal tidak semuanya merujuk pada fungsi bahasa tersebut. Leech (2013) menyatakan bahwa bahasa memiliki empat fungsi, yaitu (1) fungsi ekspresif, (2) fungsi informatif, (3) fungsi deskriptif, dan (4) argumentatif. Fungsi eskpresif berhubungan dengan ekspresi sikap psikologis seorang penutur. Bahasa dalam fungsi ini digunakan untuk mengungkapkan keadaan-keadaan internal individu. Fungsi informatif berkaitan dengan fungsi bahasa untuk menyampaikan informasi kepada orang lain mengenai keadaan-keadaan eksternal. fungsi deskriptif merujuk pada fungsi bahasa untuk memberikan objek-objek dalam dunia eksternal. Fungsi argumentatif berhubungan dengan pemakaian bahasa untuk menyajikan dan menilai argumen atau alasan. Akan tetapi, menurut Chaer dan Agustina (2015) fungsi bahasa tidak sekedar dipahami dalam fungsi sebagai alat untuk menyampaikan pemikiran, tetapi fungsi bahasa juga dapat dilihat dari sudut penutur, pendegar, topik, kode, dan amanat pembicaraan.

\section{Fungsi Kesantunan Menolak}

Fungsi kesantunan menolak pada dasarnya adalah respon bahasa yang difungsikan untuk tidak memenuhi atau tidak melaksanakan tuturan direktif yang disampaikan oleh mitra tuturnya. Selain untuk menolak, ternyata di balik tuturan respon tersebut juga memiliki fungsi lain. Berikut ini beberapa fungsi yang muncul dalam respon penolakan yang terdapat dalam film Alangkah Lucunya Negeri Ini.

\section{Fungsi Menghargai Orang Lain}

Menghargai orang lain merupakan hal yang penting kaitannya dengan menjaga kesantunan dalam komunikasi, bahkan untuk menolak sekalipun. Menghargai orang lain dalam berkomunikasi pada tuturan film Alangkah Lucunya Negeri Ini mengandung maksud khusus tertentu, antara lain untuk menjaga perasaan lawan bicara dan menjaga keharmonisan hubungan kedua penutur agar komunikasi berjalan dengan lancar. Berikut ini temuan data yang termasuk fungsi respon untuk menghargai orang lain.

Pipiit: Tunggu sebentar. Mau nitip.

(Pipiit mau masuk kembali ke rumah)

Muluk: Jangan sekarang Pit. Abang ada perlu. (Muluk terus dengan motornya)

Fungsi argumentatif kesantunan respon penolakan pada tuturan Muluk menunjukkan bahwa penutur menyampaikan alasan dia menolak permohonan mitra tuturnya karena suatu sebab. Ia menyampaikan alasan tersebut dengan maksud agar mitra tutur memahami bahwa dia tidak dapat memenuhi permohonannya. Penyampaian alasan itu bertujuan untuk mengharga atau menjaga perasaan mitra tutur agar tidak kecewa karena permohonannya tidak dapat dipenuhi. Berdasarkan konteks percakapan di atas, penutur berusia lebih tua dari mitra tutur. Penolakan yang dilakukan penutur dianggap memiliki derajat kesantunan yang baik. Hal itu sesuai dengan prinsip kesantunan, bahwa setiap tuturan yang kita ucapkan hendaknya tidak mengecewakan lawan bicara kita. 


\section{Fungsi Merendahkan Orang Lain}

Merendahkan orang lain merupakan fungsi menolak yang memiliki kesantunan tidak baik. Dalam fungsi tersebut, terdapat upaya penutur untuk membuat harga diri mitra tuturnya jatuh. Padahal dalam komunikasi, penutur dan mitra tutur diharapkan untuk saling menjaga keharmonisan hubungan masing-masing. Akan tetapi, fungsi merendahkan orang lain ini tentu melanggar ketentuan tersebut. Berikut contoh temuan data yang mendukung penjelasan di atas.

Komet : Glen, lu jangan gitu. Bedul anak buah gue. Cuman gue yang boleh ngemplang dia.

Glen : Anak buah lu bego, sih. Dines nggak ngerti.

Komet : Biarin aja dia bego. Dia bukan anak buah, lu. [FT/15.1/LAR/Dek.Rdh]

Berdasarkan konteks percakapan di atas, Glen merasa lebih pintar dan lebih berkuasa dibandingkan mitra tuturnya, sehingga fungsi argumentatif kesantunan pada tuturan tersebut dianggap kurang santun. Hal itu sesuai dengan prinsip kesantunan tentang maksim kerendahan diri. Glen dianggap melanggar prinsip kesantunan tersebut karena menggunakan argumen dengan cara merendahkan diri mitra tuturnya.

\section{Fungsi Menunjukkan Status, Kondisi, dan Emosi}

Fungsi penolakan untuk menunjukkan hal tertentu misalnya status, kondisi, dan emosi merupakan salah satu cara untuk menjelaskan kepada mitra tutur latar belakang di balik penolakan tersebut. Fungsi dengan menunjukkan status bertujuan agar mitra tutur tahu status penutur atau mitra tutur sehingga status tersebut dianggap sebab yang masuk akal untuk menolak tuturan direktif mitranya. Begitu pula dengan menunjukkan kondisi dan emosi yang dimaksudkan agar mitra tutur memahami kondisi dan emosi yang sedang dialami penutur sehingga menolak tutur direktifnya.

Muluk: Lu nggak bisa minta baik-baik?!

Komet: saya kan pencopet, bang. Bukan tukang minta-minta. [FT/01.1/PER/Dek.Sta]

Muluk: Sam, jelaskan bahwa pendidikan itu penting.

Samsul:(berbisik) Gue sendiri nggak yakin.

Muluk: Jelaskan saja menurut ilmu yang sudah elu pelajari [FT/18.1/PER/Dek.Kon]

Jupri: Eh, Sam. Nih kaos. Entar pilih gue,ya? Jangan lupa nomer 23!

(Jupri mengulurkan kaos ke Samsul. SamsuL yang lagi emisional mengembalikan kaos dengan agak kasar ke Jupri sang calon anggota DPRD.)

Samsul: Gue nggak butuh! [FT/22.1/MOH/Dek.Ems]

Kutipan data di atas menunjukkan bahwa fungsi menolak secara tidak langsung dapat menunjukkan status, kondisi, serta emosi seseorang. Berdasarkan segi kesantunan, data [FT/01.1/PER/Dek.Sta] dan [FT/18.1/PER/Dek.Kon] dianggap memiliki kesantunan karena dalam tuturan respon tersebut meski penutur melakukan penolakan, tuturan yang disampaikan menunjukkan bahwa penolakan yang dilakukan dilatarbelakangi faktor dalam diri penutur dan disampaikan dengan kalimat yang logis dan beralasan. Sementara data [FT/22.1/MOH/Dek.Ems], penolakan disampaikan dengan lugas dan tidak basa-basi disertai suara tuturan yang meninggi menandakan emosi penuturnya sedang tidak baik.

\section{Fungsi Menantang}

Menantang merupakan upaya melawan atau mengajak seseorang melakukan hal yang dianggap kurang positif, misalnya menantang berkelahi. Fungsi menantang kaitannya dengan menolak tuturan direktif tentu menunjukkan bahwa penutur tersebut tidak ingin memenuhi tutur direktif mitra tuturnya.

Komet: Bos bilang, urus anak buah masingmasing. Kalo lu mau ngemplang kepala, kemplang aja kepala anak buah lu.

Glen: Terserah gue. Sekarang kepala lu aja yang gue kemplang, ya? [FT/15.2/NAS/Int.Ttg].

Fungsi respon menolak dengan menantang mitra tuturnya seperti contoh di atas dianggap melanggar kesantunan dalam berbahasa. Jelas ditunjukkan bahwa penutur menantang dan dapat menimbulkan kerugian pada mitra tuturnya. Dalam kesantunan berbahasa, penutur diharapkan meminimalisir kerugian pada diri orang lain, sebaliknya berusaha untuk memaksimalkan kerugian pada dirinya sendiri. Ketidaksantunan yang muncul pada percakapan di atas dilatarbelakangi oleh usia dan status sosial penutur dan mitra tutur. Berdasarkan konteks percakapan di atas, penutur dan mitra tutur adalah remaja. Remaja menggunakan berbagai kesopanan dalam bahasa mereka sambil berkomunikasi tergantung pada komposisi audiens Kesopanan tersebut dirancang sebagai respon terhadap topik wacana, konteks yang berlaku, dan sifat audiensi seseorang yang dibentuk (Kariithi, 2016). Penutur yang masih remaja menganggap mitra tuturnya memiliki usia dan status sosial yang sama, sehingga merasa tidak perlu menggunakan kesantunan dalam merespon tuturan tersebut. 


\section{Fungsi Kesantunan Melaksanakan}

Respon melaksanakan tuturan direktif adalah respon yang digunakan untuk menunjukkan bahwa penutur atau perespon bersedia untuk memenuhi tuturan direktif mitra tuturnnya. Respon melaksanakan tersebut memiliki banyak fungsi selain memang untuk menujukkan kesanggupan untuk memenuhi tuturan direktifnya. Sama halnya dengan wujud kesantunan, fungsi bahasa tersebut dapat muncul baik dari respon secara verbal maupun nonverbal. Berikut adalah fungsi-fungsi bahasa kaitannya untuk melaksanakan tuturan direktif yang ditemukan dalam film Alangkah Lucunya Negeri Ini.

\section{Fungsi Menghargai}

Melaksanakan atau memenuhi permintaan merupakan salah satu upaya untuk menghargai mitra tutur kita. Menghargai orang lain atau mitra tutur dalam berkomunikasi juga cara agar komunikasi berjalan dengan lancar sehingga tujuan dalam komunikasi dapat dicapai bersama-sama. Kaitannya dengan kesantunan tuturan direktif, fungsi bahasa untuk menghargai adalah kunci agar mitra tutur merasa dianggap berharga atas tutur direktif yang sudah disampaikan.

Pipit: Bagusan juga berternak jangkrik, Bang. Saya lihat di tipi prospeknya bagus, selain buat makanan burung juga bisa buat makan ikan arwana.

Muluk: Oke nanti abang pikirin lagi deh. [FL/05.1/NAS/Dek. Hrg]

Respon melaksanakan yang dilakukan dengan fungsi menghargai orang lain di atas termasuk memiliki kesantunan yang baik. Kesantunan respon melaksanakan berupa fungsi ekspresif yang disampaikan penutur dalam kalimat (b) merupakan cara agar mita tuturnya lega karena saran atau nasihat yang diberikan akan ditindaklanjuti oleh penutur. Kesantunan bahasa tersebut sesuai dengan yang disampaikan oleh Pranowo (2012) bahwa bahasa yang digunakan seseorang haruslah menjaga perasaan mitra tutur, agar tuturan tersebut sama-sama dikehendaki dan diinginkan oleh kedua belah pihak.

\section{Fungsi Meminta Penjelasan}

Meminta penjelasan terjadi apabila seseorang tidak paham atau tidak tahu harus berbuat sesuatu dengan kondisi yang dialaminya. Dalam merespon tuturan direktif, meminta penjelasan menunjukkan bahwa penutur tersebut berusaha memenuhi tuturan direktif tersebut apabila sudah memeroleh kejelasan dari mitra tuturnya.

Bang Jarot: Baik, saya akan hajar mereka supaya mau.

Muluk: Oh, jangan.

Bang Jarot: Jadi bagaimana?

Muluk: Ini bagian proses pendidikan, penyadaran. Mungkin harus lebih bersabar. [FL/16.1/LAR/Int.Jls]

Respon melaksanakan dengan fungsi untuk meminta penjelasan yang dituturkan oleh penutur (e) dianggap santun, karena penutur berupaya untuk berusaha meminta penjelasan atau pendapat mitra tuturnya terlebih dahulu sebelum menentukan tindakan. Dalam suatu komunikasi, penutur dikatakan memiliki kesantunan karena penutur tersebut berupaya untuk menemukan kemufakatan di antara kedua belah pihak, yakni penutur dan mitra tuturnya.

\section{Fungsi Melarang}

Melarang adalah memerintahkan seseorang agar tidak melakukan sesuatu. Respon melaksanakan dengan fungsi melarang artinya seseorang memenuhi permintaan tersebut disertai dengan syarat yang berupa larangan. Larangan itu merupakan syarat agar penutur bersedia melaksanakan tuturan direktif yang diminta oleh mitra tuturnya.

Samsul: Ayo Kalong, maju. Bacakan puisi kamu.

Kalong: (bangkit dan maju. Cengengesan dulu)

Kalong: Jangan diketawain ya. [FL/21.01/PER/Imp.Lar]

Respon melaksanakan dengan fungsi melarang yang dituturkan oleh penutur (e) dianggap kurang santun. Respon melaksanakan tersebut dianggap kurang santun karena penutur tidak memberikan pilihan atau menekan pihak mitra tutur untuk mematuhi larangan dengan mengharuskan untuk tidak tertawa. Dalam suatu komunikasi, penutur dikatakan memiliki kesantunan apabila memberikan pilihan kepada mitra tutur. Semakin tuturan itu memungkinkan mitra tutur untuk menentukan pilihan yang banyak dan leluasa maka semakin santunlah tuturan itu.

\section{Fungsi Mengajak}

Mengajak berfungsi agar mitra tutur kita mau melakukan hal yang akan kita lakukan secara bersama-sama. Mengajak menjadi salah satu respon melaksanakan karena dalam respon tersebut, selain penutur bersedia memenuhi permintaan direktif mitra tuturnya penutur juga ingin mitra tuturnya untuk memenuhi ajakannya. 
Kalong: Jangan diketawain ya. (b)

Samsul: Ya, mari kita dengarkan. Kita resapkan makna yang terkandung didalamnya. [FL/21.02/LAR/Imp.Ajk]

Respon melaksanakan dengan fungsi mengajak yang disampaikan oleh Samsul merupakan hal yang santun. Penutur menginformasikan dengan menghimbau mitra tuturnya yang lain dalam rangka memenuhi permintaan mitra tuturnya. Kesantunan bahasa yang disampaikan penutur (a) sesuai dengan prinsip kesantunan yang disampaikan oleh Leech, yakni tentang maksim kesepakatan, yang mana penutur harus berusaha memaksimalkan kesetujuan antara penutur dan mitra tuturnya. Penutur berusaha mengajak atau memberi contoh yang baik agar kegiatan yang dia rencanakan dapat berjalan dengan baik.

\section{Strategi Kesantunan Respon Tuturan Direktif dalam Film Alangkah Lucunya Negeri Ini}

Strategi bertutur adalah cara seseorang menyampaikan tuturanya. Strategi atau cara bertutur dibagi menjadi dua, yakni secara langsung dan tidak langsung. Rahardi (2015) menjelaskan bahwa tindak tutur langsung adalah tindak tutur yang dinyatakan sesuai dengan strategi kalimatnya, sedangkan tindak tutur tidak langsung adalah tindakan yang dinyatakan secara tidak langsung oleh strategi kalimatnya. Saksomo (2012) menyebutkan bahwa cara mengungkapkan tindak tutur langsung digunakan untuk memberi informasi, menanyakan, memerintah, atau mengajak lawan bicara dengan mengungkapkannya secara langsung. Strategi penyampaian tidak langsung dilakukan ketika mengungkapkan maksud atau fungsi dari tuturannya secara tidak langsung. Strategi bertutur juga menunjukkan kesantunan seseorang dalam merespon suatu tuturan, baik respon menolak maupun melaksanakan. Banyak faktor yang melatarbelakangi cara seseorang untuk menunjukkan kesantunannya dalam berbahasa. Jarak sosial, formalitas topik, dan perbedaan kekuasaan mungkin memengaruhi kepatuhan terhadap kesopanan serta dapat membentuk perilaku dengan beberapa cara, (Suzila dan Yusri, 2012).

\section{Strategi Kesantunan Menolak}

Strategi menolak merupakan cara seseorang menyampaikan tuturannya kaitannya untuk menolak tuturan direktif yang disampaikan oleh mitra tuturnya. Sama halnya dengan tuturan yang lain, tuturan respon dalam menolak juga disampaikan dengan cara langsung maupun tidak langsung. Strategi langsung dilakukan misalnya dengan menuturkan kata tidak, jangan, maaf, dan sebagainya yang menunjukkan bahwa penutur tersebut tidak mampu memenuhi tuturan direktif mitra tuturnya. Sementara itu, strategi tidak langsung dilakukan dengan tidak menuturkan secara jelas penolakan tersebut atau bahkan menggunakan isyarat atau tindakan yang menunjukkan bahwa penutur menolak tuturan direktif mitra tuturnya.

\section{Strategi Kesantunan Menolak Langsung}

Tindak tutur langsung merupakan tindak tutur yang memperlihatkan fungsi bahasa dalam keadaan (tindakan) langsung dan literal (tuturan yang sesuai dengan kenyataan). Djajasudarma (2014) menjelaskan bahwa tuturan atau tindak tutur langsung memiliki daya pragmatik yang jelas, sebab tuturan semacam ini mengandung maksud yang sama dengan maka performatifnya.

Jupri: Eh, Sam. Nih kaos. Entar pilih gue,ya? Jangan lupa nomer 23.

(Jupri mengulurkan kaos ke Samsul. SamsuL yang lagi emisional mengembalikan kaos dengan agak kasar ke Jupri sang calon anggota DPRD.)

Samsul: Gue nggak butuh!(b) [ST/22.1/MOH/Lsg]

Kata nggak dalam respon tuturan direktif di atas dianggap sebagai penanda dari penolakan langsung tersebut. Berdasarkan segi kesantunan, penolakan pada tuturan (a) merupakan contoh penolakan yang kurang santun. Hal itu dilatarbelakangi oleh faktor psikologi dan sosial, baik dari penutur dan mitra tutur. Dari segi psikologis, kondisi emosi Samsul sedang tidak baik, ia sedang sedih karena harus berhenti mengajar, artinya dia kembali menganggur dan tidak punya pekerjaan lagi. Dari segi sosial, Jupri calon DPR terlanjur mempunyai image bahwa janji-janji selama kampanye hanyalah bualan belaka, sehingga Samsul merasa tidak perlu mendukungnya. Kedua faktor inilah yang mempengaruhi kesantunan penolakan yang dilakukan oleh Samsul terhadap Jupri.

\section{Strategi Kesantunan Menolak Tidak Langsung}

Strategi menolak tidak langsung adalah penyampaian penolakan yang dilakukan tidak secara jelas atau lugas bahwa penutur menolak tuturan direktif yang disampaikan mitra tuturnya. Pada umumnya, strategi menolak tidak langsung dilakukan agar mitra tutur tidak kecewa atas penolakan tersebut. Hal ini tentu berkaitan dengan kesantunan dalam merespon. Strategi menolak tidak langsung dilakukan dengan beberapa cara, yakni dengan menyampaikan alasan, pertanyaan permintaan. Bahkan ada penolakan yang disertai ancaman. Jelas bahwa penggunaan ancaman untuk menolak menunjukkan ketidaksantunan.

Komet: Bos bilang, urus anak buah masing-masing. Kalo lu mau ngemplang kepala, kemplang aja kepala anak buah lu! Glen: Terserah gue. Sekarang kepala lu aja yang gue kemplang, ya? [ST/15.2/NAS/TL.Anc] 
Respon penolakan tuturan Glen dilakukan dengan strategi tidak langsung menggunakan ancaman. Hal itu tampak pada kalimat lu aja yang gue kemplang, ya? Dari kalimat tersebut dapat dimaknai bahwa penutur tidak ingin melakukan nasihat seperti yang disampaikan mitra tuturnya. Penolakan dengan menggunakan strategi tidak langsung dengan ancama merupakan cara yang tidak santun untuk menolak. Berdasarkan prinsip kebijaksanaan, ancaman yang dituturkan oleh penutur menimbulkan kerugian bagi mitra tuturnya. Ketidaksantunan yang terdapat dalam tuturan itu dilatarbelakangi oleh faktor kedudukan dan usia.

\section{Strategi Kesantunan Melaksanakan}

Strategi kesantunan respon melaksanakan tuturan direktif pada film Alangkah Lucunya Negeri Ini merupakan cara yang digunakan untuk menyampaikan bahwa penutur bersedia memenuhi atau melaksana tuturan direktif yang disampaikan oleh mitra tuturnya. Respon melaksanakan tersebut dapat dilakukan dengan strategi langsung maupun tidak langsung.

\section{Strategi Kesantunan Melaksanakan Langsung}

Strategi langsung dalam respon melaksanakan ditandai dengan munculnya ungkapan-ungkapan yang menunjukkan bahwa penutur bersedia melakukan hal yang diminta oleh mita tuturnya. Ungkapan-ungkapan tersebut antara lain oke,iya,dan baiklah. Berikut ini adalah beberapa data dengan strategi kesantunan respon melaksanakan langsung yang muncul pada film Alangkah Lucunya Negeri Ini.

Pipit: Bagusan juga berternak jangkrik, Bang. Saya lihat di tipi prospeknya bagus, selain buat makanan burung dapat juga makan ikan arwana.

Muluk: Oke nanti abang pikirin lagi deh. [SL/05.1/NAS/Lsg]

Strategi langsung yang muncul pada tuturan tersebut ditandain dengan munculnya kata oke yang menunjukkan kesediaan penutur untuk melaksanakan atau menerima nasihat yang diberikan oleh mitra tuturnya. Strategi langsung dalam melaksanakan respon tuturan direktif yang dilakukan Muluk di atas dikatakan santun. Kesantunan strategi langsung yang muncul pada tuturan di atas dilatarbelakangi oleh tiga hal, yakni kedudukan sosial, usia, dan jenis kelamin. Pertama, berdasarkan kedudukan sosial, penutur lebih tinggi tingkat sosialnya dalam hal pendidikan dibandingkan dengan mitra tutur. Kedua, dari segi usia, penutur lebih tua dari mitra tuturnya. Dari kedua aspek di atas, penutur mungkin saja menggunakan cara yang kurang santun sepertinya dengan isyrarat anggukan atau acungan jempol untuk merespon nasihat orang yang lebih muda darinya. Ketiga, dari segi jenis kelamin, penutur laki-laki memang cenderung menggunakan bahasa yang santun dengan perempuan dibandingkan ketika berinteraksi dengan sesama laki-laki. Adel, Davoudi, dan Ramezanzadeh (2016) menyampaikan bahwa penggunaan penanda kesopanan penutur pria hampir sama dengan yang digunakan wanita dan strategi kesopanan positif terutama digunakan oleh penutur pria. Strategi melaksanakan langsung yang digunakan oleh penutur di atas dianggap santun dan menghormati mitra tutur yang memberikan nasihat padanya.

\section{Strategi Kesantunan Melaksanakan Tidak Langsung}

Strategi melaksanakan tidak langsung merupakan pelaksanaan yang dilakukan penutur kepada mitra tuturnya baik menggunakan bahasa, maupun isyarat, atau tindakan. Akan tetapi, bahasa, isyarat, maupun tindakan tersebut tidak secara langsung menunjukkan bahwa penutur tersebut bersedia melaksanakan atau memenuhi permohonan, perintah, nasihat, ataupun tuturan direktif lainnya yang disampaikan oleh mitra tutur. Penggunaan strategi tidak langsung pada respon melaksanakan dianggap sebagai bentuk kesantunan berbahasa.

Muluk: Ini bagian proses pendidikan, penyadaran. Mungkin harus lebih bersabar.

Bang Jarot: (mengangguk-angguk) [SL/16.2/NAS/TL. Isy]

Strategi respon melaksanakan dengan isyarat pada percakapan di atas ditunjukkan dengan anggukkan kepala sebagai tanda bahwa Bang Jarot menyetujui nasihat dari mitra tuturnya. Anggukan kepala sebagai isyarat tersebut dikatakan sebagai strategi tidak langsung, karena tidak ada tuturan yang menyertai isyarat tersebut yang mana tuturan itu menunjukkan bahwa penutur bersedia menuruti nasihat mitra tuturnya. Strategi respon tidak langsung dengan isyarat pada data di atas merupakan strategi yang santun. Hal tersebut dilatarbelakangi oleh beberapa hal, yakni usia, status sosial, dan pendidikan. Dari segi usia, perespon merupakan orang yang lebih tua dari mitra tuturnya. Dari segi pendidikan, mitra tutur lebih berpendidikan dibandingkan dengan perespon.

Dari segi status sosial, perespon adalah bos dalam lingkungan copet tersebut sehingga dia memiliki kekuasaan yang lebih dibandingkan mitra tuturnya. Dalam komunitas tertentu, seseorang yang paling dihormati dan memiliki status sosial tertinggi dapat mendorong orang lain atau mitra tuturnya untuk memilih bahasa yang paling santun ketika berkomunikasi dengan orang tersebut (Ardhiarta, 2013), tetapi tidak sedikit seseorang yang merasa status sosialnya tinggi tidak berbahasa dengan santun kepada mitra tutur yang memiliki status sosial di bawahnya. Tentu data di atas tidak sepenuhnya mendukung pernyataan tersebut. 


\section{SIMPULAN}

Penelitian ini fokus pada kesantunan respon terhadap tuturan direktif yang muncul pada film Alangkah Lucunya Negeri Ini, (1) kesantunan respon tersebut dideskripsikan melalui wujud kesantunan respon tuturan direktif dalam film, (2) fungsi kesantunan respon tuturan direktif dalam film, dan (3) mendeskripsikan strategi kesantunan respon tuturan direktif dalam film. Hasil penelitian menunjukkan bahwa berdasarkan wujudnya, kesantunan respon memiliki dua wujud yakni berupa (1) verbal, terdiri atas kalimat deklaratif, kalimat interogatif, imperatif dan (2) nonverbal, terdiri atas isyarat dan tindakan. Berdasarkan fungsi kesantunannya, respon tuturan direktif memiliki dua fungsi utama, yakni fungsi menolak dan melaksanakan. Masingmasing fungsi tersebut dibagi lagi menjadi fungsi khusus, yakni (1) menghargai orang lain, (2) merendahkan orang lain, (3) menunjukkan status, (4) menunjukkan kondisi, (5) menunjukkan emosi, (6) menolak persetujuan, (7) menantang, (8) meminta penjelasan, (9) melarang, (10) mengajak, dan (11) mencapai tujuan mitra tutur. Ketiga, berdasarkan strateginya kesantunan respon ditunjukkan dengan dua cara, yakni secara langsung dan tidak langsung. Kesantunan respon terhadap tuturan direktif yang muncul dalam film Alangkah Lucunya Negeri Ini dilatarbelakangi oleh banyak faktor, di antaranya jenis kelamin, usia, status sosial atau kedudukan, kondisi, dan emosi seseorang.

Berdasarkan hasil penelitian yang telah dijelaskan, peneliti mengemukakan dua saran. Saran tersebut dijelaskan sebagai berikut. Pertama, bagi ahli bahasa/peneliti bisa menjadikan penelitian ini sebagai acuan untuk melaksanakan penelitian lanjutan. Kedua, bagi pendidik dan pengembang bahan ajar bisa menjadikan hasil penelitian ini sebagai salah satu bahan ajar untuk memahamkan pelajar kesantunan respon terhadap tuturan direktif dan memanfaatkan film yang telah dikaji menjadi media pembelajaran bagi siswa.

\section{DAFTAR RUJUKAN}

Adel, S. M. R., Davoudi, M., \& Ramezanzadeh, A. (2016). A Qualitative Study of Politeness Strategies Used by Iranian EFL Leraners in a Class Blog. Iranian Journal of Language Teaching Research, 4(1), 47-62.

Ardhiarta, A. A. (2013). Kesantunan Berbahasa Dalam Interaksi Sosial di Pondok Pesantren Darul Ulum Jombang: Suatu Kajian Pragmatik. Skriptorium, 2(1), 1-7.

Chojimah, N. (2015). Refusal and Politeness Strategies in Relation to Social Status: A Case of Face-threatening Act among Indonesian University Students. Theory and Practice in Language Studies, 5(5), 906-918. http://dx.doi.org/10.17507/tpls.0505.04

Goddard, C. (2012). Directive Speech Acts in Malay (Bahasa Melayu): an Ethnopragmatic Perspective. Cahiers de Praxematique, 38, 113-143.

Febriana, S. I. (2011). Tuturan Responsif Siswa terhadap Tuturan Direktif Guru dalam Wacana Interaksi Kelas di SMA Negeri 1 Batu. Tesis tidak diterbitkan. Universitas Negeri Malang, Malang.

Kariithi, F. (2016). Politeness Strategies Used by Youth in Their Language Use. IOSR Jounals of Humanities and Social Science, 21(7), 70-72.

Kristanti, F. (2015). Tindak Tutur Direktif Dalam Dialog Film “Ketika Cinta Bertasbih” Karya Chaerul Umam. Tesis tidak diterbitkan. Universitas Negeri Yogyakarta, Yogyakarta.

Masfufah, N. (2010). Kesantunan Bentuk Tuturan Direktif di Lingkungan Sma Negeri 1 Surakarta (Sebuah Kajian Sosiopragmatik). Tesis tidak diterbitkan. Universitas Sebelas Maret, Surakarta.

Nurjamily, W.O. (2015). Kesantunan Berbahasa Indonesia dalam Lingkungan Keluarga: Kajian Sosiopragmatik. Jurnal Humanika, 3(15), 1-18.

Suzila, T. S. T. I., \&Yusri, M. N. M. (2012). Politeness: Adolescents in Disagreements. International Journal of Social Science and Humanity, 2(2), 1-6.

Trianton, T. (2013). Film sebagai Media Belajar. Yogyakarta: Graha Ilmu.

Yasri, H. L., \& Mulyani, E. (2016). Efektivitas Penggunaan Media Film untuk Meningkatkan Minat dan Hasil Belajar Ekonomi Siswa Kelas X. Harmoni Sosial: Jurnal Pendidikan IPS, 3(1), 138-149. 10.21831/hsjpi.v3i2.7931

Yuka, A. (2009). POSITIVE: Politeness Strategies in Oral Communication I Textbooks. The Economic Journal of Takashi City University of Economic, 52(1), 59-70. 